\title{
Statistical Studies of the Physicochemical Analytic Results of a Series of Synthetic Calcium Hydroxyapatite Containing Carbonate and Sodium
}

\author{
Faouzia Rockh B. Hadj Yahia, Ismail Khattech \\ Faculty of Science, Chemistry Department, Applied Thermodynamics Laboratory, Tunis El Manar, Tunisia \\ Email: faouziarockh1@Gmail.com
}

Received 5 March 2014; revised 7 April 2014; accepted 15 April 2014

Copyright (C) 2014 by authors and Scientific Research Publishing Inc. This work is licensed under the Creative Commons Attribution International License (CC BY). http://creativecommons.org/licenses/by/4.0/ (c) () Open Access

\section{Abstract}

The objective of this study is to present a simple method of statistical calculation that allowed us to determine the relationship between the different data obtained from the characterization of the synthetic carbonated apatites containing sodium, in order to find the fundamental substitution mechanism(s) for incorporation of $\mathrm{Na}^{+}$and $\mathrm{CO}_{3}^{2-}$ and to establish the general formula. For that, a series of hydroxyapatites containing carbonate and sodium ( $\mathrm{Na}-\mathrm{CO}_{3} \mathrm{HAps}$ ) has been obtained by the precipitation method. All the compounds were characterized by infrared spectra (IR), powder X-ray diffraction (PXRD) and elemental analysis. The statistical treatment of the experiment result allows us to determine the relationship between one variable and the change in the other and to found the fundamental substitution mechanism(s) for incorporation of $\mathrm{Na}^{+}$and $\mathrm{CO}_{3}^{2-}$. Analysis of variance (ANOVA) allows us to test the models proposed.

\section{Keywords}

Carbonated Calcium Hydroxyapatite Containing Sodium $\mathrm{Na}_{-} \mathrm{CO}_{3} \mathrm{HAps}$, Statistical Studies, Multiple Linear Regression, Analysis of Variance (ANOVA)

\section{Introduction}

Carbonated calcium hydroxyapatite containing sodium and/or potassium, magnesium etc. is the most important mineral compound in human dental, enamel and bone [1] [2]. We can also found this type of apatite in sedimen- 
tary phosphate apatite [3]. Consequently, these materials have necessitated studies of the effects of ions, such as $\mathrm{CO}_{3}^{2-} \mathrm{Na}^{+}, \mathrm{Mg}^{2+}$, on the physicochemical properties and especially the mode of $\mathrm{CO}_{3}^{2-} \mathrm{Na}^{+}$incorporation in apatite structure. But, the complexity of biological and sedimentary phosphates apatite has returned these studies very difficultly.

For this reason, multiple techniques have been used to prepare these products, with wet chemical methods and solid-state reactions [4]-[14]. Carbonate incorporation in synthetic carbonated calcium hydroxyapatites " $\mathrm{CO}_{3}$ HAp" has been classified as either type A or type $\mathrm{B}$ depending on the mode of $\mathrm{CO}_{3}^{2-}$ substitution: $\mathrm{CO}_{3}^{2-}$ for $\mathrm{OH}^{-}$type A substitution and $\mathrm{CO}_{3}^{2-}$ for $\mathrm{PO}_{4}^{3-}$ type $\mathrm{B}$ substitution [10] [11].

In the precipitation of " $\mathrm{CO}_{3} \mathrm{HAps",} \mathrm{different} \mathrm{products} \mathrm{are} \mathrm{obtained} \mathrm{if} \mathrm{the} \mathrm{calcium} \mathrm{solution} \mathrm{is} \mathrm{added} \mathrm{to} \mathrm{the}$ phosphate plus carbonate solution "direct" rather than vice versa "inverse" apatite [6] [8] [12]-[14]. All these products are B-Apatite, but it seems that the maximum possible carbonate content was greater in the "direct" apatite compared with "inverse" apatite [13]. Na-free B-type " $\mathrm{CO}_{3} \mathrm{HAps"} \mathrm{has} \mathrm{been} \mathrm{prepared} \mathrm{with} \mathrm{a} \mathrm{maximum}$ $\mathrm{CO}_{3}^{2-}$ content between $10 \mathrm{wt} \%$ at $14 \mathrm{wt} \%$. In the presence of ions such as $\left(\mathrm{Na}^{+}, \mathrm{K}^{+}\right.$or $\left.\mathrm{Mg}^{2+}\right)$, we have a coupled substitution. With $\mathrm{Na}^{+}$for $\mathrm{Ca}^{2+}$, B-type apatite "Na-CO $\mathrm{CO}_{3} \mathrm{HAps"} \mathrm{contains} \mathrm{up} \mathrm{to} 22 \mathrm{wt} \% \mathrm{CO}_{3}^{2-}$ [14].

Based on some studies, such as EPR and IR spectroscopy, X-ray and neutron diffraction, chemical analyses, infrared and Raman spectroscopy, the crystallite size, chemical composition and physicochemical nature of synthetic apatite have been determinated. But there have been multiple studies, speculations and controversy about the mechanism(s) by which $\mathrm{CO}_{3}^{2-}$ and alkali metal(s) are incorporated in the apatite lattice [15]-[20]. According to De Maeyer et al., the fundamental substitution mechanisms for the incorporation of $\mathrm{Na}^{+}$and $\mathrm{CO}_{3}^{2-}$ in hydroxyl apatite "HAp" can be described using six basic processes [21].

1) $\mathrm{Ca}^{2+}+\mathrm{PO}_{4}^{3-}+\mathrm{OH}^{-} \leftrightarrow \mathrm{V}^{\mathrm{Ca}}+\mathrm{CO}_{3}^{2-}+\mathrm{V}^{\mathrm{OH}}$

2) $\mathrm{Ca}^{2+}+2 \mathrm{PO}_{4}^{3-} \leftrightarrow \mathrm{V}^{\mathrm{Ca}}+2 \mathrm{CO}_{3}^{2-}$

3) $\mathrm{Ca}^{2+}+\mathrm{PO}_{4}^{3-} \leftrightarrow \mathrm{CO}_{3}^{2-}+\mathrm{Na}^{+}$

4) $2 \mathrm{Ca}^{2+}+\mathrm{OH}^{-} \leftrightarrow \mathrm{V}^{\mathrm{OH}}+\mathrm{Na}^{+}$

5) $\mathrm{PO}_{4}^{3-} \leftrightarrow \mathrm{CO}_{3}^{2-}+\mathrm{OH}^{-}$

6) $2 \mathrm{OH}^{-} \leftrightarrow \mathrm{V}^{\mathrm{OH}}+\mathrm{CO}_{3}^{2-}$

where $\mathrm{V}^{\mathrm{X}}$ is the vacancy on a regular apatite lattice site occupied by $\mathrm{X}$.

Moreover, these authors propose a coupling of different fundamental mechanisms in a fixed proportion, leading to the definition of apparently new mechanisms. The composition of B-type of $\mathrm{Na}^{-} \mathrm{CO}_{3} \mathrm{HAps}$ is determined by the occurrence of one or more of these fundamental mechanisms. Thus, these authors suggest that the stoichiometry would be given by:

$$
\mathrm{Ca}_{10-(a+b+d+c+e)} \mathrm{Na}_{(c+d)}\left(\mathrm{PO}_{4}\right)_{6-(a+2 b+c+d+e)}\left(\mathrm{CO}_{3}\right)_{(a+2 b+c+d+e)}(\mathrm{OH})_{2-(a+d)+e}
$$

where $a, b, c, d$ and $e$ are the contribution per unit cell of basic substitutions (I to $\mathrm{V}$ ) resulting in the fundamental substitution mechanisms for incorporation of $\mathrm{Na}^{+}$and $\mathrm{CO}_{3}^{2-}$ in the crystal lattice of hydroxyapatite "HAp".

The aim of the present study is to present a statistical method which allows us to determine the relationship between the obtained values and experimental conditions and to estimate the change in one variable from the given increase or decrease in another. The analysis of variance (ANOVA) allows us to test the mathematical model. Finally, the statistical method allows us to find the fundamental substitution mechanism(s) for incorporation of $\mathrm{Na}^{+}$and $\mathrm{CO}_{3}^{2-}$. So, the stoichiometry of the solid can be described as a function of the contributions of each mechanism to the composition of the unit cell.

\section{Experimental Procedure}

\subsection{Preparation of $\mathrm{Na}-\mathrm{CO}_{3} \mathrm{HAps}$}

The preparation method is described in detail elsewhere [12] [13], In brief, The precipitated $\mathrm{Na}-\mathrm{CO}_{3} \mathrm{HAps}$ were prepared by dripping calcium solution $0.03 \mathrm{M}\left(\mathrm{Ca}\left(\mathrm{NO}_{3}\right)_{2} \cdot 4 \mathrm{H}_{2} \mathrm{O}\right)$ into a phosphate solution $0.008 \mathrm{M}$ of $\left(\mathrm{Na}_{2} \mathrm{HPO}_{4} \cdot 12 \mathrm{H}_{2} \mathrm{O}\right)$ which contains also different concentrations of $\left(\mathrm{Na}_{2} \mathrm{CO}_{3}\right)$ such as the molar ratio $R$ :

$0<R=n_{\mathrm{CO}_{3}^{2-}} / n_{\mathrm{PO}_{4}^{3-}} \leq 60$. So that, the concentrations of $\left[\mathrm{CO}_{3}^{2-}\right]$ and $\left[\mathrm{Na}^{+}\right]$were varied in the hydrolysis solution: $0.098 \mathrm{M} \leq\left[\mathrm{Na}^{+}\right] \leq 0.998 \mathrm{M}, \quad 0.04 \mathrm{M} \leq\left[\mathrm{CO}_{3}^{2-}\right] \leq 0.49 \mathrm{M}$. Then, the concentration ratio $\left[\mathrm{Na}^{+}\right] /\left[\mathrm{CO}_{3}^{2-}\right] \cong 2$. 
After hydrolysis which took $3 \mathrm{~h}$, the precipitates were filtered, washed abundantly with hot distilled water $\left(95^{\circ} \mathrm{C}\right)$, dried for $12 \mathrm{~h}$ at $70^{\circ} \mathrm{C}$ and then heated at $400^{\circ} \mathrm{C}$ in air for $24 \mathrm{~h}$ in order to eliminate inter- and intracrystalline water.

\subsection{Characterization}

\subsubsection{Infrared Spectroscopy and X-Ray Diffraction}

$\mathrm{Na}-\mathrm{CO}_{3} \mathrm{HAps}$ samples are characterized by IR absorption spectroscopy and X-ray diffraction. In infra-Red, we use pellets of absorption. They are prepared using the usual $\mathrm{KBr}$ disk technique. It consists in mixing $1 \mathrm{mg}$ of powder of a sample of $\mathrm{Na}-\mathrm{CO}_{3} \mathrm{HAp}$ with $300 \mathrm{mg} \mathrm{KBr}$ then pressed at 6 psi. The pellets so prepared were then scanned on a Shimadzu IR spectrometer in the range $(4000-400) \mathrm{cm}^{-1}$.

Powder X-ray diffraction analysis for the $\mathrm{Na}-\mathrm{CO}_{3} \mathrm{HAps}$ samples were carried out using an $\mathrm{X}$-ray diffractometer MRD with a generator $(40 \mathrm{kV}$ and $40 \mathrm{~mA})$. After indexation of the full pattern, cell parameters were refined using the program "WINCELL"

\subsubsection{Chemical Analysis and Density Measurements}

The dehydrated samples were subjected to a chemical analysis. The phosphorus content of precipitates is determined by colorimetry after complexation with vanado-molybdate [22]. The sodium and calcium content are obtained by atomic absorption spectroscopy and the carbonate content was determined by coulometry method (release of $\mathrm{CO}_{2}$ by dissolution in acid). The hydroxide content $\% \mathrm{OH}$ was calculated on the basis of electro neutrality. Density of the solids was measured by a flotation method [13].

\section{Results}

\subsection{Physical Analysis}

The infra-Red spectrums presented in Figure 1 show that they are typical of apatite containing B-type carbonate [13]. The assignment of absorption bands was made according to the studies [12] [13]. IR analyses of the samples show the effect of increasing $\mathrm{CO}_{3}^{2-}$ and $\mathrm{Na}^{+}$on the spectral properties of apatites. However, increasing $\mathrm{CO}_{3}^{2-}$ and $\mathrm{Na}^{+}$contents caused increasing of the intensities of the $\mathrm{CO}_{3}^{2-}$ absorption bands at $1420-1460 \mathrm{~cm}^{-1}$ $\left(v_{3} \mathrm{C}-\mathrm{O}\right)$ and $872 \mathrm{~cm}^{-1}\left(v_{2} \mathrm{C}-\mathrm{O}\right)$ and decreasing in the resolution of $\mathrm{PO}_{4}^{3-}\left(v_{3} \mathrm{P}-\mathrm{OH}\right)$ absorption band at 1032 $\mathrm{cm}^{-1}$, The shoulder observed at $740 \mathrm{~cm}^{-1}$ is attributed to the $v_{\mathrm{L}}$ mode of $\mathrm{OH}^{-}$close neighbors to $\mathrm{Na}^{+}$ions [13].

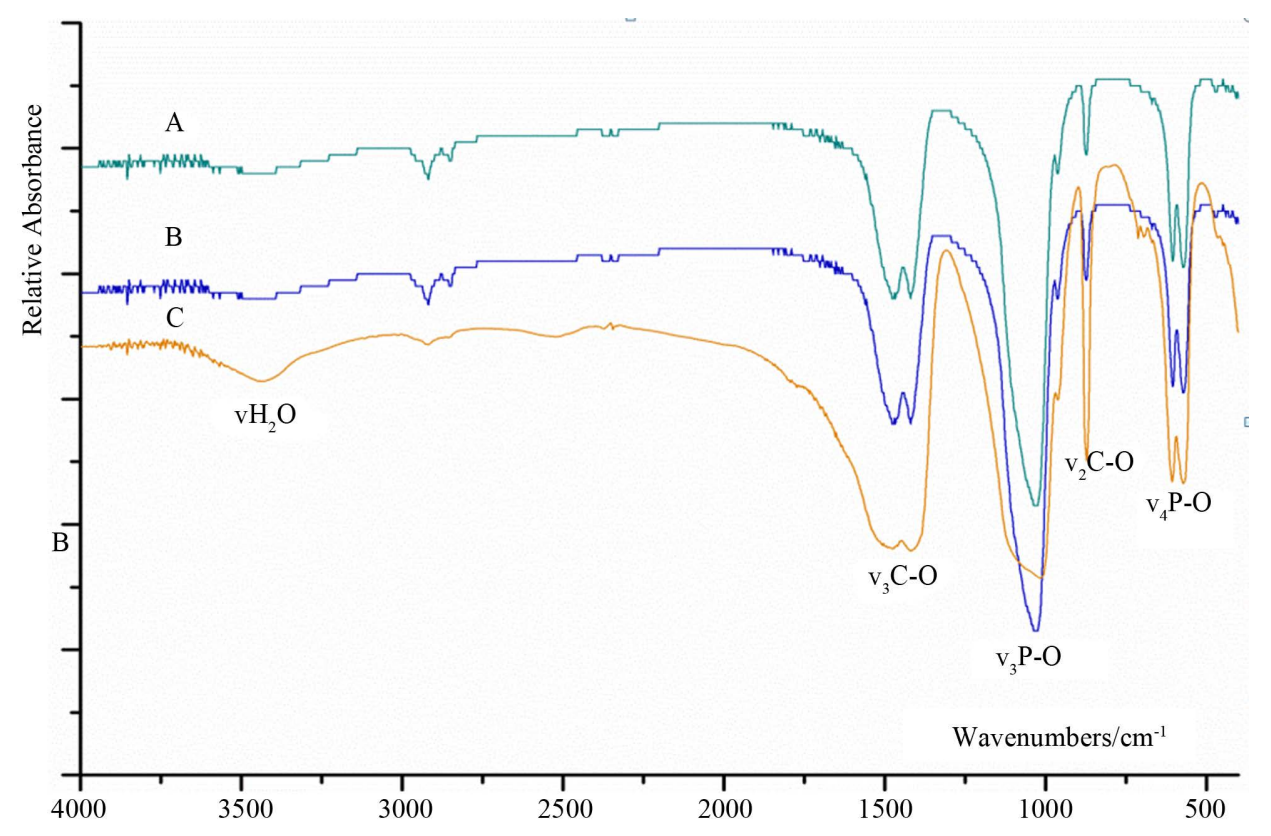

Figure 1. Absorption Spectra of $\mathrm{Na}-\mathrm{CO}_{3} \mathrm{Haps}$ obtained from solutions with: (A) $R=5$, (B) 15 AND (C) 25. 
In Figure 2 we presented the X-ray diffraction patterns. The peaks are relatively sharp and well resolved and can all attributed to the hexagonal crystal form of hydroxyapatite, but some shifts of peaks position can be observed, reflecting a change in unit cell dimensions due to incorporation of $\mathrm{CO}_{3}^{2-}$ and $\mathrm{Na}^{+}$. This allows us to consider our samples as pure well-crystallized phases of apatite type. The results of dimensions " $a$ " and " $c$ " and the volume of the hexagonal apatitic unit cell obtained from X-Ray analysis as well as the densities of the compounds allow determining the molar weight $(\mathrm{Mw})$. The results are grouped together in Table 1.

\subsection{Chemical Results}

The compositions of samples in Weight \% determined by chemical analysis are displayed in Table 2 . The results of quantitative analysis of phosphorus, calcium and sodium were determined with standards deviations 0.17; 0.03 and 0.09 respectively and the amount of $\mathrm{CO}_{3}$ was determined on relative uncertainty $2 \%$.

The results of the chemical and physical analysis (Table 1 and Table 2) allowed us to calculate the number of each ion $\mathrm{X}$ per unit cell, $n_{x}$ according to:

$$
n_{x}=\frac{\% \mathrm{X} \cdot M}{100 \cdot M_{x}},
$$

where $M\left(\rho \cdot V_{\text {cell }} N\right)$ is the molar mass, $V_{\text {cell }}$ is the unit cell volume, $M_{x}$ is the atomic or ionic mass of $\mathrm{X}$ and $N$ Avogadro's constant. The amount of $\mathrm{OH}$ ions was calculated taking into account the electroneutrality of each compound. Table 3 gathers the calculation results.

\section{Discussion}

As in the case of the reference [23], the last column of Table 3 shows that the sum of the number of phosphate and carbonate per unit cell $O_{p}=n_{\mathrm{PO}_{4}}+n_{\mathrm{CO}_{3}}$ is approximately equals to 6 with experimental error as well as the XRD and IR spectra clearly demonstrate that the samples "Na-CO $3 \mathrm{CAps}_{3}$ " of this study are pure B-type carbonated apatites, this indicates that $\mathrm{CO}_{3}^{2-}$ substitutes for $\mathrm{PO}_{4}^{3-}$ on a 1:1 basis which agrees with the fundamental substitution mechanisms for B-type $\mathrm{CO}_{3}^{2-}$ [21] [23]-[25]. On the basis of the observation, the real number of each ion per unit cell can be obtained using the following equation:

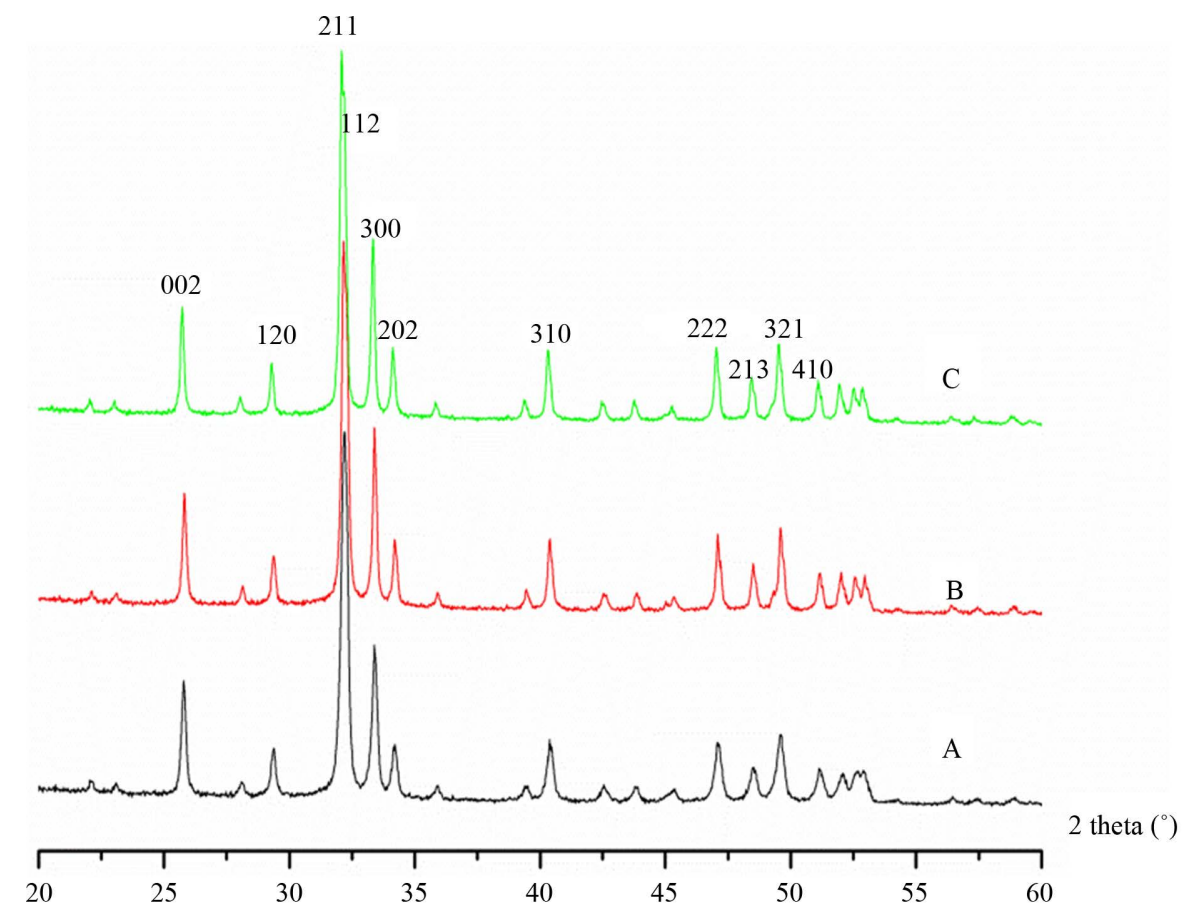

Figure 2. XRD patterns of synthetic apatites obtained from solutions with: (A) $R=5$, (B) $15,(\mathrm{C}) 25$. 
Table 1. Values of lattice parameters " $a$ ", " $c$ " and volume molar; density and weight (Mw) of the prepared samples.

\begin{tabular}{cccccc}
\hline \multicolumn{5}{c}{ Lattice parameters } \\
\hline Apatites & density & a-Axis $(\AA)$ & c-Axis $(\AA)$ & Volume $/ \AA^{3}$ & M/g mol $^{-1}$ \\
\hline (1) $\mathrm{R}=5$ & 2.79 & $9.3550 \pm 0,0017$ & $6.9221 \pm 0,0011$ & 524.63 & 881.5 \\
$(2) \mathrm{R}=10$ & 2.78 & $9.3784 \pm 0.0013$ & $6.9276 \pm 0.0009$ & 527.68 & 883.5 \\
(3) $\mathrm{R}=15$ & 2.79 & $9.3262 \pm 0.0004$ & $6.9003 \pm 0.0003$ & 519.77 & 873.4 \\
(4) $\mathrm{R}=20$ & 2.77 & $9.3584 \pm 0.0015$ & $6.9440 \pm 0.0010$ & 526.55 & 878.5 \\
(5) $\mathrm{R}=25$ & 2.79 & $9.3375 \pm 0.0015$ & $6.9318 \pm 0.0010$ & 523.41 & 879.5 \\
(6) $\mathrm{R}=30$ & 2.71 & $9.3236 \pm 0.0017$ & $6.9363 \pm 0.0011$ & 522.19 & 852.3 \\
(7) $\mathrm{R}=35$ & 2.72 & $9.2854 \pm 0.0012$ & $6.9148 \pm 0.0008$ & 516.32 & 845.9 \\
(8) $\mathrm{R}=40$ & 2.73 & $9.3059 \pm 0.0013$ & $6.9241 \pm 0.0009$ & 519.29 & 853.8 \\
(9) $\mathrm{R}=45$ & 2.80 & $9.3001 \pm 0.0009$ & $6.9163 \pm 0.0006$ & 518.06 & 874.3 \\
(10) $\mathrm{R}=50$ & 2.72 & $9.3008 \pm 0.0016$ & $6.9202 \pm 0.0011$ & 518.42 & 849.3 \\
(11) $\mathrm{R}=55$ & 2.76 & $9.2710 \pm 0.0015$ & $6.9230 \pm 0.0012$ & 515.32 & 856.6 \\
(12) $\mathrm{R}=60$ & 2.77 & $9.2691 \pm 0.0005$ & $6.9216 \pm 0.0010$ & 515.01 & 859.2 \\
\hline
\end{tabular}

Table 2. Chemical composition (weight \%) and total mass balance $\Sigma \%$ of Na$\mathrm{CO}_{3} \mathrm{HAps}$ prepared from solutions with $0 \prec R=n_{\mathrm{CO}_{3}^{2-}} / n_{\mathrm{PO}_{4}^{3-}} \leq 60 / 1$.

\begin{tabular}{ccccccc}
\hline & \multicolumn{5}{c}{ Composition \%w } \\
\hline Apatites & $\mathrm{Ca}^{2+}$ & $\mathrm{Na}^{+}$ & $\mathrm{PO}_{4}^{3-}$ & $\mathrm{CO}_{3}^{2-}$ & $\mathrm{OH}^{-}$ & $\Sigma \%$ \\
\hline$(1) \mathrm{R}=5$ & 37.71 & 3.47 & 46.62 & 10.47 & 3.65 & 101.93 \\
$(2) \mathrm{R}=10$ & 37.53 & 3.95 & 45.87 & 12.63 & 3.04 & 103.03 \\
(3) $\mathrm{R}=15$ & 37.02 & 4.70 & 44.71 & 13.36 & 3.36 & 103.16 \\
(4) $\mathrm{R}=20$ & 37.24 & 4.62 & 42.97 & 14.67 & 3.69 & 103.19 \\
(5) $\mathrm{R}=25$ & 36.74 & 4.90 & 41.36 & 15.26 & 4.00 & 102.26 \\
(6) $\mathrm{R}=30$ & 35.75 & 5.74 & 39.15 & 17.98 & 3.43 & 102.05 \\
(7) $\mathrm{R}=35$ & 35.85 & 5.38 & 39.54 & 17.71 & 3.18 & 101.67 \\
$(8) \mathrm{R}=40$ & 35.31 & 5.40 & 37.66 & 18.56 & 3.27 & 100.21 \\
(9) $\mathrm{R}=45$ & 33.95 & 6.03 & 35.65 & 19.25 & 3.26 & 98.15 \\
$(10) \mathrm{R}=50$ & 34.72 & 6.12 & 35.21 & 21.39 & 3.01 & 100.45 \\
(11) $\mathrm{R}=55$ & 34.33 & 7.30 & 36.14 & 22.44 & 2.46 & 102.66 \\
(12) $\mathrm{R}=60$ & 34.70 & 6.68 & 33.89 & 23.71 & 2.80 & 101.77 \\
\hline
\end{tabular}

$$
n_{\mathrm{X}}=\frac{\% \mathrm{X}}{M_{\mathrm{X}}} \frac{6}{\left(\% \mathrm{P} / M_{\mathrm{P}}+\% \mathrm{CO}_{3} / M_{\mathrm{CO}_{3}}\right)}
$$

Similarly, we have calculated the number of vacancies on $\mathrm{Ca}^{2+}$ and $\mathrm{OH}^{-}$lattice sites respectively:

$$
n_{\mathrm{V}} \mathrm{Ca}=10-n_{\mathrm{Ca}}-n_{\mathrm{Na}}
$$


and

$$
n_{\mathrm{v}^{\mathrm{OH}}}=2-n_{\mathrm{OH}}
$$

The results of these calculations are summarized in Table 4. The errors in Table 4 were estimated by means of error propagation theory.

Table 3. Unit cell composition of $\mathrm{Na}-\mathrm{CO}_{3} \mathrm{AHps}$ calculated on the basis of the chemical composition and by means of Equation (1).

\begin{tabular}{ccccccc}
\hline \multicolumn{5}{c}{ Composition } \\
\hline Sample & $n_{\mathrm{Ca}}$ & $n_{\mathrm{Na}}$ & $n_{\mathrm{PO}_{4}}$ & $n_{\mathrm{CO}_{3}}$ & $n_{\mathrm{OH}}$ & $O_{\mathrm{P}}$ \\
\hline$(1)$ & 8.609 & 1.687 & 4.327 & 1.538 & 2.081 & 5.86 \\
$(2)$ & 8.359 & 1.933 & 4.265 & 1.859 & 1.354 & 6.12 \\
$(3)$ & 8.451 & 2.266 & 4.112 & 1.945 & 2.105 & 6.06 \\
$(4)$ & 8.371 & 2.266 & 3.977 & 2.150 & 1.988 & 6.13 \\
$(5)$ & 8.095 & 2.388 & 3.829 & 2.237 & 1.875 & 6.07 \\
$(6)$ & 7.880 & 2.726 & 3.510 & 2.552 & 1.995 & 6.06 \\
$(7)$ & 7.865 & 2.533 & 3.523 & 2.498 & 1.882 & 6.02 \\
$(8)$ & 7.485 & 2.561 & 3.387 & 2.643 & 1.486 & 6.03 \\
$(9)$ & 7.410 & 2.813 & 3.277 & 2.801 & 1.959 & 6.04 \\
$(10)$ & 7.198 & 2.881 & 3.146 & 3.025 & 1.063 & 6.17 \\
$(11)$ & 7.360 & 3.341 & 3.262 & 3.207 & 1.748 & 6.47 \\
$(12)$ & 7.443 & 3.077 & 3.060 & 3.390 & 1.830 & 6.45 \\
\hline
\end{tabular}

Table 4. Unit cell compositions of $\mathrm{Na}-\mathrm{CO}_{3} \mathrm{Aaps}$ calculated on the basis of the chemical composition and by means of following Equation (2).

\begin{tabular}{|c|c|c|c|c|c|c|c|}
\hline \multicolumn{8}{|c|}{ Composition of apatite } \\
\hline sample & $n_{\mathrm{Ca}^{2+}}$ & $n_{\mathrm{Na}^{+}}$ & $n_{\mathrm{PO}_{4}^{3-}}$ & $n_{\mathrm{CO}_{3}^{2-}}$ & $n_{\mathrm{OH}^{-}}$ & $n_{\mathrm{v}^{\mathrm{Ca}}}$ & $n_{\mathrm{v}^{\text {он }}}$ \\
\hline (1) & $8.502 \pm 0.073$ & $1.361 \pm 0.078$ & $4.426 \pm 0.052$ & $1.573 \pm 0.037$ & $1.939 \pm 0.239$ & $0.137 \pm 0.108$ & $0.061 \pm 0.239$ \\
\hline (2) & $8.118 \pm 0.073$ & $1.488 \pm 0.077$ & $4.178 \pm 0.051$ & $1.821 \pm 0.044$ & $1.547 \pm 0.241$ & $0.393 \pm 0.106$ & $0.452 \pm 0.241$ \\
\hline (3) & $8.008 \pm 0.073$ & $1.768 \pm 0.077$ & $4.073 \pm 0.051$ & $1.926 \pm 0.046$ & $1.712 \pm 0.245$ & $0.223 \pm 0.108$ & $0.288 \pm 0.245$ \\
\hline (4) & $8.017 \pm 0.075$ & $1.730 \pm 0.077$ & $3.895 \pm 0.051$ & $2.105 \pm 0.051$ & $1.868 \pm 0.255$ & $0.253 \pm 0.110$ & $0.131 \pm 0.255$ \\
\hline (5) & $7.990 \pm 0.079$ & $1.854 \pm 0.078$ & $3.787 \pm 0.051$ & $2.212 \pm 0.054$ & $2.048 \pm 0.261$ & $0.155 \pm 0.113$ & $-0.048 \pm 0.261$ \\
\hline (6) & $7.534 \pm 0.082$ & $2.105 \pm 0.077$ & $3.474 \pm 0.051$ & $2.526 \pm 0.063$ & $1.699 \pm 0.270$ & $0.361 \pm 0.114$ & $0.301 \pm 0.270$ \\
\hline (7) & $7.559 \pm 0.083$ & $1.973 \pm 0.077$ & $3.510 \pm 0.051$ & $2.489 \pm 0.062$ & $1.581 \pm 0.268$ & $0.468 \pm 0.113$ & $0.419 \pm 0.268$ \\
\hline (8) & $7.504 \pm 0.083$ & $2.000 \pm 0.077$ & $3.370 \pm 0.051$ & $2.629 \pm 0.066$ & $1.638 \pm 0.276$ & $0.496 \pm 0.116$ & $0.362 \pm 0.276$ \\
\hline (9) & $7.315 \pm 0.086$ & $2.260 \pm 0.079$ & $3.235 \pm 0.051$ & $2.763 \pm 0.070$ & $1.655 \pm 0.283$ & $0.425 \pm 0.118$ & $0.344 \pm 0.283$ \\
\hline (10) & $7.161 \pm 0.087$ & $2.196 \pm 0.077$ & $3.059 \pm 0.050$ & $2.941 \pm 0.075$ & $1.460 \pm 0.286$ & $0.642 \pm 0.117$ & $0.539 \pm 0.286$ \\
\hline (11) & $6.826 \pm 0.088$ & $2.524 \pm 0.076$ & $3.025 \pm 0.049$ & $2.974 \pm 0.075$ & $1.151 \pm 0.281$ & $0.650 \pm 0.114$ & $0.849 \pm 0.281$ \\
\hline (12) & $6.922 \pm 0.090$ & $2.316 \pm 0.076$ & $2.847 \pm 0.048$ & $3.153 \pm 0.081$ & $1.314 \pm 0.293$ & $0.761 \pm 0.108$ & $0.686 \pm 0.293$ \\
\hline
\end{tabular}


Comparing our experiment data with the data available in the literature [24]-[26], we can found that the presents results are in agreement with those of reference [25], though, this series was prepared by hydrolysis of monetite in solution with varied $\mathrm{CO}_{3}^{2-}$ and alkali metal $\mathrm{Na}^{+}$concentration.

So, it may be said in the present study, that the fundamental substitution mechanisms (I, III and IV) could account for the incorporation of $\mathrm{CO}_{3}^{2-}$ and $\mathrm{Na}^{+}$in the HAp lattice. If $a, c$ and $d$ are the contributions of mechanisms I, III and IV respectively, thus,

and

$$
\begin{gathered}
a=n_{\mathrm{V}} \mathrm{Ca} \\
c=n_{\mathrm{CO}_{3}}-a
\end{gathered}
$$

$$
d=n_{\mathrm{Na}}-c
$$

and the generic formula has the following expression:

$$
\mathrm{Ca}_{10-(a+d+c)} \mathrm{Na}_{(c+d)}\left(\mathrm{PO}_{4}\right)_{6-(a+c+d)}\left(\mathrm{CO}_{3}\right)_{(a+c+d)}(\mathrm{OH})_{2-(a+d)}
$$

\section{Statistical Studies}

The objective of this study is to construct a mathematical model which allows us to estimate the change in $Y$ the dependent variable from a given increase or decrease in $X$ the independent variable and to determine which mechanism(s) is related with experimental conditions.

The mathematical model is expressed as:

$$
Y_{i}=\beta_{0}+\Sigma_{1}^{j} \beta_{j} X_{j, i}+\varepsilon_{i}
$$

where $\varepsilon_{i}$ is the random variable drawn from $N\left(0, \sigma^{2}\right), \beta_{0}$ and $\beta_{j}$ are the estimated regression coefficients. The model assumes that their deviation $\varepsilon$ from the line is normally distributed with means 0 and constant variances $\sigma^{2}$.

Least square method [26] allows calculating the regression and correlation coefficients, the variance of the $\beta$ parameters and to test the null hypothesis $H_{0}: \beta_{j}=0$ and their significances level. The analysis of variance for the linear regression or the $\mathrm{F}$ test allows us to be confident that at least one of $\mathrm{X}$-variable contributes to the regression. The theoretical basis of these calculations is given in references [12] [26].

\subsection{Multiple Linear Regression of $Y=c / a$ Crystallographic Parameters Ratio on $X_{1}=\% \mathrm{CO}_{3}^{2-}$ and $X_{2}=\% \mathrm{Na}^{+}$the $\%$ Weightions in the Hexagonal Apatite Lattice}

In attempts to disentangle and to measure the effects of the insertion of $\mathrm{CO}_{3}^{2-}$ and $\mathrm{Na}^{+}$ions on the hexagonal apatite lattice dimensions, we have constructed a multiple linear regression on two $X$-variables where, $X_{1}=\% \mathrm{CO}_{3}^{2-}$ and $X_{2}=\% \mathrm{Na}^{+}$(data Table 2 ) and $Y$ is the estimate ratio of the hexagonal lattice dimensions (data Table 1). The results of the calculation values of the different correlations coefficients, the estimated values of $\beta_{0}, \beta_{1}$ and $\beta_{2}$, the variances and t-test of $\beta_{1}$ and $\beta_{2}$ are summarized in Table 5(a). The analysis of the variance for the linear regression or the F-test is given in Table $5(\mathrm{~b})$.

The multiple linear regression (Table 5(a)) indicates that the ratio of the hexagonal lattice dimensions of $\mathrm{Na}-\mathrm{CO}_{3} \mathrm{Aps}$ " $c / a$ " vary linearly with the carbonate and sodium content according to:

$$
c / a=0.730+3.23 \times 10^{-4}\left(\% \mathrm{CO}_{3}^{2-}\right)+1.25 \times 10^{-3}\left(\% \mathrm{Na}^{+}\right)
$$

The analysis of variance (Table 5(b)/ANOVA) shows further that F-test $=100.5$ is higher than criterion $\mathrm{F}(5 \%$; $2.9)=4.26$. This allowed us to rejet $\mathrm{H}_{0}: \beta_{1}=\beta_{2}=0$ and affirm that at least one of the predictors is linearly associated to the response.

T-test of of the estimated regression coefficients $\beta_{1}$ and $\beta_{2}$ has shown that $\beta_{2}$ and $\beta_{1}$ are significant at $70 \%$ level.

\subsection{Multiple Linear Regression of $Y=n_{\mathrm{CO}_{2}} / n_{\mathrm{P}}$ or $n_{\mathrm{Na}} / n_{\mathrm{P}}$ the Molar Ratio in Na-CO $\mathrm{CO}_{3} \mathrm{HAps}$ Solid on the Concentration of $\mathrm{Na}^{+}: X_{1, i}$ and the Concentration of $\mathrm{CO}_{3}^{2-}: X_{2, i}$ in Aqueous Solution}

To understand the influence of the experimental conditions on the composition of these apatites (data Table 4), we conducted a multiple linear regression [22] on two $X$-variables where, $X_{1}$ and $X_{2}$ are the $\mathrm{Na}^{+}$and $\mathrm{CO}_{3}^{2-}$ ions 
Table 5. calculation for fitting a multiple linear regression analysis of the estimated $Y=c / a$ the ratio of the lattice parameters of $\mathrm{Na}-\mathrm{CO}_{3} \mathrm{HApson}$ carbonate and sodium contents $X_{1}=\mathrm{wt} \%$ $\mathrm{CO}_{3}, X_{2}=\mathrm{wt} \% \mathrm{Na}$. (a) Calculation of regression, correlation coefficients and variances, (b) F-test: Analysis of Variance.

(a)

\begin{tabular}{cccccccc}
\hline Coefficients of correlation & \multicolumn{2}{c}{ Coefficients of regression } & Variances & \multicolumn{2}{c}{ t-test } \\
\hline$R^{2}$ & 0.953 & & & & & & \\
$R_{X_{1} Y}$ & 0.972 & $\beta_{0}$ & 0.730 & & & & \\
$R_{X_{2} Y}$ & 0.973 & $\beta_{1}$ & $3.1 \times 10^{-4}$ & $v\left(\beta_{1}\right)$ & $8.46 \times 10^{-8}$ & $t\left(\beta_{1}\right)$ & 1.11 \\
$R_{X_{2} X_{1}}$ & 0.985 & $\beta_{2}$ & $1.25 \times 10^{-3}$ & $v\left(\beta_{2}\right)$ & $9.77 \times 10^{-7}$ & $t\left(\beta_{2}\right)$ & 1.26 \\
\hline
\end{tabular}

(b)

\begin{tabular}{ccccc}
\hline Source of variation & DF & Sum of Squares & Mean Square & Fobs \\
\hline Regression & 2 & $21.85 \times 10^{-5}$ & $10.9 \times 10^{-5}$ & 100.54 \\
Deviations & 10 & $1.08 \times 10^{-5}$ & $1.08 \times 10^{-6}$ & \\
Total & 12 & $22.9 \times 10^{-5}$ & $1.91 \times 10^{-6}$ & \\
\hline
\end{tabular}

concentrations in solution and $Y$ is the estimates molar ratios of $n_{\mathrm{CO}_{3}} / n_{\mathrm{P}}$ and $n_{\mathrm{Na}} / n_{\mathrm{P}}$ in the solids. The values of the different correlations coefficients, the estimated values of $\beta_{0}, \beta_{1}$ and $\beta_{2}$, their variances and the F-test or the test of the variance are summarized in Table 6 and Table 7.

The multiple linear regression (Table 6(a)) indicates that the molar $\mathrm{CO}_{3} / \mathrm{P}$ ratio of the Na-CO $\mathrm{CAps}_{3}$ vary linearly with the concentrations of carbonate and sodium in solution according to:

$$
n_{\mathrm{CO}_{3}} / n_{\mathrm{P}}=1.49 \times 10^{-4}-32.96 \cdot\left[\mathrm{CO}_{3}^{2-}\right]+17.28 \cdot\left[\mathrm{Na}^{+}\right]
$$

The result of the F-test (Table $6(\mathrm{~b})$ ) $\mathrm{F}=635.5$ and the individual t-test of the $\beta$ 's Table $6 \mathrm{~b}$ for $\beta_{1}, \mathrm{t}=-7.82$. For $\beta_{2}, \mathrm{t}=8.26$ confirm that the molar $\mathrm{CO}_{3} / \mathrm{P}$ ratio of $\mathrm{Na}-\mathrm{CO}_{3} \mathrm{HAps}$ solid is significantly depends on both concentrations of carbonate $\left[\mathrm{CO}_{3}^{2-}\right]=X_{1}$ and sodium $\left[\mathrm{Na}^{+}\right]=X_{2}$ in aqueous solution. However, constantly we have $\left[\mathrm{Na}^{+}\right] \cong 2\left[\mathrm{CO}_{3}^{2-}\right]$, thus the expression in brackets $\left(32.96 \cdot\left[\mathrm{CO}_{3}^{2-}\right]+17.28 \cdot\left[\mathrm{Na}^{+}\right]\right)$, hardly varied, thus, $\mathrm{CO}_{3} / \mathrm{P}$ molar ratio is constant. This shows that for $\left[\mathrm{CO}_{3}^{2-}\right] /\left[\mathrm{Na}^{+}\right]$concentration ratio in solution constant the increase on molar $\mathrm{CO}_{3}^{2-}$ in solid is equal to the decrease on molar $\mathrm{PO}_{4}^{3-}$. Thus, the molar ratio in the solid is not significantly influenced by the increase of $\mathrm{Na}^{+}$and $\mathrm{CO}_{3}^{2-}$ ions in solution. This result is in a good agreement with the results in literature [24].

The multiple linear regression (Table $7(\mathrm{a})$ ) indicates that the molar $\mathrm{Na} / \mathrm{P}$ ratio of $\mathrm{Na}-\mathrm{CO}_{3} \mathrm{HAps}$ vary linearly with the carbonate content according to:

$$
n_{\mathrm{Na}} / n_{\mathrm{P}}=0.198-0.249 \cdot\left[\mathrm{Na}^{+}\right]+1.85 \cdot\left[\mathrm{CO}_{3}^{2-}\right] \text {. }
$$

An analysis of variance (Table 7(b)/ANOVA), further shows that F-test $=43.5$ is higher than criterion $\mathrm{F}(1 \%$, $2.10)=7.56$, this allowed us to rejet $\mathrm{H}_{0}: \beta_{1}=\beta_{2}=0$ and affirm that at least one of the predictors is linearly associated to the response. T-test of the regression coefficients $\beta_{1}$ and $\beta_{2}$ has shown for $\beta_{1}$, $\mathrm{t}=-0.45$ signifiant at $30 \%$ level. For $\beta_{2}, \mathrm{t}=1.67$ signifiant at $80 \%$ level.

\subsection{Multiple Linear Regression of the Estimated Molar Content of Calcium $Y=n_{\mathrm{Ca}^{2+}}$ on $X_{1}=n_{\mathrm{Na}^{+}}$and $X_{2}=n_{\mathrm{CO}_{3}^{2-}}$ the Molar Contents of Sodium and Carbonate in the Solid}

The examination of Table 4 showed too that $n_{\mathrm{Ca}}$ molar content of the solid decreases when $n_{\mathrm{CO}_{3}}$ and $n_{\mathrm{Na}}$ incorporate increase. To determine the relationship between these three variables given in Table 4 , a multiple linear regression analysis was undertaken. The results are summarized in Table 8.

From Table 8, the multiple linear regression analysis shows that the relationship between these quantities is given by equation: 
Table 6. Calculation for fitting a multiple linear regression of the estimated $Y_{i}=n_{\mathrm{CO}_{3}} / n_{\mathrm{p}}$ molar ratio in Na- $\mathrm{CO}_{3} \mathrm{HAps}$ solid on $X_{1}=\left[\mathrm{Na}^{+}\right]$and $X_{2}=\left[\mathrm{CO}_{3}^{2-}\right]$ the concentrations in solution. (a) Calculation of regression and correlation coefficients and variances, (b) Values of F-test: Analysis of Variance.

(a)

\begin{tabular}{cccccccc}
\hline Coefficient of Correlation & \multicolumn{2}{c}{ Coefficients of Regression } & \multicolumn{2}{c}{ Variances } & \multicolumn{2}{c}{ t-test } \\
\hline$R^{2}$ & 0.99 & & & & & & \\
$R_{X_{1} Y}$ & 0.969 & $\beta_{0}$ & 0,00014 & & & & \\
$R_{X_{2} Y}$ & 0.972 & $\beta_{1}$ & -32.96 & $v\left(\beta_{1}\right)$ & 17.72 & $t\left(\beta_{1}\right)$ & -7.82 \\
$R_{X_{2} X_{1}}$ & 0.999 & $\beta_{2}$ & 17.28 & $v\left(\beta_{2}\right)$ & 4.37 & $t\left(\beta_{2}\right)$ & 8.26 \\
\hline
\end{tabular}

(b)

\begin{tabular}{ccccc}
\hline Source of Variation & DF & Sum of Squares & Mean Square & Fobs \\
\hline Regression & 2 & 1.0799 & 0.5399 & 635.6 \\
Deviations & 10 & $8.49 .10^{-3}$ & $8.79 .10^{-4}$ & \\
Total & 12 & 1.0884 & 0.0907 & \\
\hline
\end{tabular}

Table 7. Calculation for fitting a multiple linear regression analysis of the estimated $Y=$ $n_{\mathrm{Na}} / n_{\mathrm{P}}$ molar ratio in Na-CO${ }_{3} \mathrm{HAps}$ solid on $X_{1}=\left[\mathrm{Na}^{+}\right]$and $X_{2}=\left[\mathrm{CO}_{3}^{2-}\right]$ the concentrations in solution. (a) Calculation of regression and correlation coefficients and variances, (b) Values of F-test: Analysis of Variance.

(a)

\begin{tabular}{cccccccc}
\hline Coefficients of correlation & Coefficients of regression & \multicolumn{2}{c}{ Variances } & \multicolumn{2}{c}{ t-test } \\
\hline$R^{2}$ & 0.897 & & & & & & \\
$R_{X_{1} Y}$ & 0.935 & $\beta_{0}$ & 0.198 & & & & \\
$R_{X_{2} Y}$ & 0.948 & $\beta_{1}$ & -0.249 & $v\left(\beta_{1}\right)$ & 0.30 & $t\left(\beta_{1}\right)$ & -0.45 \\
$R_{X_{2} X_{1}}$ & 0.992 & $\beta_{2}$ & 1.854 & $v\left(\beta_{2}\right)$ & 1.23 & $t\left(\beta_{2}\right)$ & 1.67 \\
\hline
\end{tabular}

(b)

\begin{tabular}{ccccc}
\hline Source of variation & DF & Sum of Squares & Mean Square & $F_{\text {obs }}$ \\
\hline Regression & 2 & 0.5618 & 0.2809 & 43.56 \\
Deviations & 10 & 0.0645 & 0.00645 & 0.0522 \\
Total & 12 & 0.626 & \\
\hline
\end{tabular}

$$
n_{\mathrm{Ca}}=10.07-0.383 \cdot\left(n_{\mathrm{Na}^{+}}\right)-0.698\left(n_{\mathrm{CO}_{3}^{2-}}\right)
$$

From the intercept of the following equation it can seen that, within experimental error, a carbonate-free apatite $\left(n_{\mathrm{CO}_{3}}=0\right)$ contains $10 \mathrm{Ca}^{2+}$ ions per unit cell. The expression in brackets $\left(-0.383 n_{\mathrm{Na}^{+}}-0.698 \cdot n_{\mathrm{CO}_{3}^{2-}}\right)$ shows that the number of $\mathrm{Ca}^{2+}$ ions in the unit cell decreases with increasing of $\mathrm{Na}^{+}$and $\mathrm{CO}_{3}^{2-}$ numbers for about one $\mathrm{Ca}^{2+}$ ion.

The analysis of variance (Table $8(\mathrm{~b})$ ), further shows that F-test $=379.4$ is higher than criterion $\mathrm{F}(5 \%, 2.9)=$ 4.26, this allowed us to rejet $\mathrm{H}_{0}: \beta_{1}=\beta_{2}=0$ and affirm that at least one of the predictors is linearly associated to 
the response. T-tests of the regression coefficients $b_{1}$ and $b_{2}$ show that the value of: $\beta_{1}$ is signifiant at $80 \%$ level and for $\beta_{2}$ is signifiant at $90 \%$ level.

\subsection{Multiple Linear Regression of $Y=a, c$ or $d$ the Contributions of Mechanisms I, III and IV on $X_{1}=\left[\mathrm{Na}^{+}\right]$and $X_{2}=\left[\mathrm{CO}_{3}^{2-}\right]$ the Concentrations in Solution}

For determine which mechanism(s) is related with experimental conditions, we have undertaken a statistical analysis [26] of the values of $a, c$ and d the contribution of the mechanisms I, III and IV (Table 9) calculated according to the following Equations (5)-(7) as a function of $\mathrm{Na}^{+}$and $\mathrm{CO}_{3}^{2-}$ concentrations in aqueous solution. Results of these calculations are summarized in Tables 10-12.

Table 8. Calculation for fitting a multiple linear regression of the estimated $Y_{i}=n_{\mathrm{Ca}^{2+}}$ the molar number of calcium as a function of carbonate and sodium contents $X_{1, i}=n_{\mathrm{Na}}$ and $X_{2, i}=n_{\mathrm{CO}_{3}}$ in the solid Na-CO $\mathrm{CO}_{3} \mathrm{Haps}$ (a) Calculation of regression, correlation coefficients and variances, (b) F-test: Analysis of Variance.

(a)

\begin{tabular}{|c|c|c|c|c|c|c|c|}
\hline \multicolumn{2}{|c|}{ Coefficient of Correlation } & \multicolumn{2}{|c|}{ Coefficients of Regression } & \multicolumn{2}{|c|}{ Variances } & \multicolumn{2}{|c|}{ t-test } \\
\hline$R^{2}$ & 0.987 & & & & & & \\
\hline$R_{X_{1} Y}$ & -0.985 & $\beta_{0}$ & 10.06 & & & & \\
\hline$R_{X_{2} Y}$ & -0.992 & $\beta_{1}$ & -0.383 & $v\left(\beta_{1}\right)$ & 0.066 & $t\left(\beta_{1}\right)$ & -1.49 \\
\hline$R_{X_{2} X_{1}}$ & 0.983 & $\beta_{2}$ & -0.698 & $v\left(\beta_{2}\right)$ & 0.039 & $t\left(\beta_{2}\right)$ & -3.52 \\
\hline
\end{tabular}

(b)

\begin{tabular}{ccccc}
\hline Source of Variation & DF & Sum of Squares & Mean Square & Fobs \\
\hline Regression & 2 & 8.033 & 4.016 & 379.4 \\
Deviations & 10 & 0.10586 & 0.01058 & \\
Total & 12 & 8.1386 & 0.6782 & \\
\hline
\end{tabular}

Table 9. Values of ( $a, c$ and $d$ ) the estimated contribution of the mechanism I, II and IV.

\begin{tabular}{cccccc}
\hline Sample & {$\left[\mathrm{CO}_{3}^{2-}\right]$} & {$\left[\mathrm{Na}^{+}\right]$} & $\mathrm{a}$ & $\mathrm{c}$ & $\mathrm{d}$ \\
\hline 0 & 0 & 0 & 0 & 0 & 0 \\
1 & 0.098 & 0.041 & 0.137 & 1.437 & -0.076 \\
2 & 0.180 & 0.082 & 0.393 & 1.429 & 0.060 \\
3 & 0.262 & 0.123 & 0.223 & 1.704 & 0.065 \\
4 & 0.344 & 0.164 & 0.253 & 1.852 & -0.122 \\
5 & 0.426 & 0.205 & 0.155 & 2.058 & -0.203 \\
6 & 0.507 & 0.245 & 0.361 & 2.165 & -0.060 \\
7 & 0.590 & 0.287 & 0.468 & 2.023 & -0.048 \\
8 & 0.671 & 0.327 & 0.497 & 2.133 & -0.134 \\
9 & 0.753 & 0.368 & 0.425 & 2.340 & -0.080 \\
10 & 0.834 & 0.409 & 0.642 & 2.299 & -0.103 \\
11 & 0.916 & 0.450 & 0.650 & 2.325 & 0.199 \\
12 & 0.998 & 0.491 & 0.761 & 2.392 & -0.076 \\
\hline
\end{tabular}


From Table 10, the multiple linear regression analysis shows that the relationship between these quantities is given by equation:

$$
Y_{i}=a=5.68 \times 10^{-5}+5.92 \cdot\left[\mathrm{Na}^{+}\right]-10.16 \cdot\left[\mathrm{CO}_{3}^{2-}\right]
$$

An analysis of variance (Table 10(b)/ANOVA), further shows that F-test $=25.36$ is higher than criterion $\mathrm{F}$ $(5 \%, 2.9)=4.26$, this allowed us to rejet: is linearly $\mathrm{H}_{0}: \beta_{1}=\beta_{2}=0$ and affirm that at least one of the predictors associated to the response. The individuals t-test of the regression show that for $\beta_{1}, \mathrm{t}=0.79$ signifiant at $60 \%$ level and for $\beta_{2}, \mathrm{t}=-0.70$ signifiant at $50 \%$ level.

Table 10. Calculation for fitting a multiple linear regression of the estimated $Y_{i}=\left(a=n_{\mathrm{v}^{\mathrm{a}}}\right)$ the contribution of the mechanism I on the concentration of $\mathrm{Na}^{+}: X_{1, i}$ and the concentration of $\mathrm{CO}_{3}^{2-}: X_{2, i}$ in aqueous solution, (a) Calculation of regression and correlation coefficients and variances, (b) Values of F-test: Analysis of Variance.

(a)

\begin{tabular}{cccccccc}
\hline Coefficient of Correlation & Coefficients of Regression & Variances & \multicolumn{2}{c}{ t-test } \\
\hline$R^{2}$ & 0.835 & & & & & & \\
$R_{X_{1} Y}$ & 0.909 & $\beta_{0}$ & $5.68 \times 10^{-5}$ & & & & \\
$R_{X_{2} Y}$ & 0.908 & $\beta_{1}$ & 5.92 & $v\left(\beta_{1}\right)$ & 51.35 & $t\left(\beta_{1}\right)$ & 0.79 \\
$R_{X_{2} X_{1}}$ & 0.999 & $\beta_{2}$ & -10.16 & $v\left(\beta_{2}\right)$ & 208.2 & $t\left(\beta_{2}\right)$ & -0.70 \\
\hline
\end{tabular}

(b)

\begin{tabular}{ccccc}
\hline Source of Variation & DF & Sum of Squares & Mean Square & Fobs \\
\hline Regression & 2 & 0.506 & 0.253 & 25.36 \\
Deviations & 10 & 0.0998 & 0.010 & \\
Total & 12 & 0.606 & 0.050 & \\
\hline
\end{tabular}

Table 11. Calculation for fitting a multiple linear regression of the estimated $Y_{i}=\left(c=n_{\mathrm{CO}_{3}}-n_{\mathrm{V}} \mathrm{Ca}\right)$ the contribution of the mechanism III on the concentration of $\mathrm{Na}^{+}: X_{1, i}$ and the concentration of $\mathrm{CO}_{3}^{2-}: X_{2, i}$ in aqueous solution, (a) Calculation of regression and correlation coefficients and variances, (b) Values of F-test: Analysis of Variance.

(a)

\begin{tabular}{cccccccc}
\hline Coefficients of Correlations & \multicolumn{2}{c}{ Coefficients of Regression } & \multicolumn{2}{c}{ Variances } & \multicolumn{2}{c}{ t-test } \\
\hline$R^{2}$ & 0.970 & & & & & & \\
$R_{X 1 Y}$ & 0.825 & $\beta_{0}$ & $7.61 \times 10^{-4}$ & & & & \\
$R_{X 2 Y}$ & 0.818 & $\beta_{1}$ & 87.85 & $v\left(\beta_{1}\right)$ & 76.93 & $t\left(\beta_{1}\right)$ & 10.01 \\
$R_{X 2 X 1}$ & 0.999 & $\beta_{2}$ & -173.54 & $v\left(\beta_{2}\right)$ & 311.83 & $t\left(\beta_{2}\right)$ & -9.83 \\
\hline
\end{tabular}

(b)

\begin{tabular}{ccccc}
\hline Source of Variation & DF & Sum of Squares & Mean Square & Fobs \\
\hline Regression & 2 & 4.856 & 2.428 & 163.6 \\
Deviations & 10 & 0.1484 & 0.0148 & 0.417 \\
Total & 12 & 5.004 & \\
\hline
\end{tabular}


From Table 11, the multiple linear regression analysis shows that the relationship between these quantities is given by equation:

$$
Y_{i}=c=11.1 \times 10^{-4}+87.83 \cdot\left[\mathrm{Na}^{+}\right]-173.5 \cdot\left[\mathrm{CO}_{3}^{2-}\right]
$$

An analysis of variance (Table 11(b)/ANOVA), further shows that F-test $=163.55$ is higher than criterion $\mathrm{F}(5 \%, 2.9)=4.26$, this allowed us to rejet $\mathrm{H}_{0}: \beta_{1}=\beta_{2}=0$ and affirm that at least one of the predictors is linearly associated to the response. The individual t-tests on the regression coefficients $\beta_{1}$ and $\beta_{2}$ and, Hence, for $\beta_{1}, \mathrm{t}=$ 10 , for $\beta_{2}, \mathrm{t}=-9.8 \mathrm{t}\left(\beta_{1}\right)$ and $\mathrm{t}\left(\beta_{2}\right)$ are signifiants at $\mathrm{P}>99.9 \%$ level.

From Table 12, the multiple linear regression analysis shows that the relationship between these quantities is given by equation:

$$
Y_{i}=d=2.59 \times 10^{-4}-3.44 \cdot\left[\mathrm{Na}^{+}\right]+6.92 \cdot\left[\mathrm{CO}_{3}^{2-}\right]
$$

An analysis of variance (Table 12(b)/ANOVA), further shows that F-test $=0.10$ is lower than criterion $\mathrm{F}(5 \%$, $2.9)=4.26$, this test affirm that mechanism IV is unrelated to experiment conditions. The result of the present study provide that mechanisms I and III are the main in incorporation of $\mathrm{Na}^{+}$and $\mathrm{CO}_{3}^{2-}$ in $\mathrm{HAp}$.

\subsection{Multiple Linear Regression Analysis for the Determination of Formula of Unit Cell}

The determination of unit cell has been realized by a multiple linear regression between the variables $Y=n_{\mathrm{Ca}}$ and $X_{1}=a, X_{2}=c, X_{3}=d$. Least square allows calculating the regression and correlation coefficients. The sample regression (prediction equation) is:

$\hat{Y}=\beta_{0}+\beta_{1} X_{1}+\beta_{2} X_{2}+\beta_{3} X_{3}$, where $\beta_{0}, \beta_{1}, \beta_{2}, \beta_{3}$ are the estimated regression coefficients. These have been calculated from the values of correlation coefficients, variance and covariance according to the method of Scherrer [27]. The results of calculations are given in Table 13. To testing the utility of the model, we conduct the F-test according to:

$$
F=\frac{(n-m-1) \times R^{2}}{m \times\left(1-R^{2}\right)},
$$

where $n$ is sample size, $m$ is number of parameters and $(n-m-1)$ is degree of freedom.

From Table 13, the multiple linear regression analysis shows that the relationship between these quantities is given by equation:

$$
Y_{i}=n_{\text {Сa }}=10-0.989 \cdot a-1.00 \cdot c-1.00 \cdot d
$$

Table 12. Calculation for fitting a multiple linear regression of the estimated $Y=d=n_{\mathrm{Na}}-c$ the contribution of the mechanism IV on the concentration of $\mathrm{Na}^{+}: X_{1, i}$ and the concentration of $\mathrm{CO}_{3}^{2-}: X_{2, i}$ in aqueous solution, (a) Calculation of regression and correlation coefficients and variances, (b) Values of F-test: Analysis of Variance.

(a)

\begin{tabular}{cccccccc}
\hline Coefficient of Correlation & Coefficients of Regression & Variances & \multicolumn{2}{c}{ t-test } \\
\hline$R^{2}$ & 0.018 & & & & & & \\
$R_{X 1 Y}$ & -0.009 & $\beta_{0}$ & $-22 \times 10^{-4}$ & & & & \\
$R_{X 2 Y}$ & -0.007 & $\beta_{1}$ & -3.46 & $v\left(\beta_{1}\right)$ & 62.4 & $t\left(\beta_{1}\right)$ & -0.44 \\
$R_{X 2 X 1}$ & 0.999 & $\beta_{2}$ & 6.97 & $v\left(\beta_{2}\right)$ & 253.2 & $t\left(\beta_{2}\right)$ & 0.44 \\
\hline
\end{tabular}

(b)

\begin{tabular}{ccccc}
\hline Source of Variation & DF & Sum of Squares & Mean of Squares & Fobs \\
\hline Regression & 2 & 0.0025 & 0.0012 & 0.10 \\
Deviations & 10 & 0.1279 & 0.0127 & \\
Total & 12 & 0.1304 & 0.0109 & \\
\hline
\end{tabular}


Table 13. Calculation for fitting a multiple linear regression of the estimated $Y=n_{\mathrm{Ca}}=Y$ in Na- $\mathrm{CO}_{3} \mathrm{HAps}$ on the contribution of mechanism I a: $X_{1 \text { i }}$, contribution of mechanism III c: $X_{2 i}$ contribution of mechanism IV d: $X_{3 i}$.

\begin{tabular}{ccccccccc}
\hline \multicolumn{2}{c}{ Coefficient of Correlation } & \multicolumn{2}{c}{ Coefficients of Regression } & \multicolumn{2}{c}{ Variances } & \multicolumn{2}{c}{ Co-variances } \\
\hline$R^{2}$ & 0.998 & $\beta_{0}$ & 10.00 & $\operatorname{var}(Y)$ & 0.626 & $\operatorname{Cov}\left(X_{1}, Y\right)$ & -0.149 \\
$R_{X_{1} Y}$ & -0.875 & $\beta_{1}$ & -0.989 & $v\left(X_{1}\right)$ & 0.047 & $\operatorname{Cov}\left(X_{2}, Y\right)$ & -0.473 \\
$R_{X_{2} Y}$ & -0.965 & $\beta_{2}$ & -1.00 & $v\left(X_{2}\right)$ & 0.385 & $\operatorname{Cov}\left(X_{3}, Y\right)$ & -0.003 \\
$R_{X_{3} Y}$ & -0.038 & $\beta_{3}$ & -1.00 & $v\left(X_{3}\right)$ & 0.010 & $\operatorname{Cov}\left(X_{1} X_{2}\right)$ & 0.099 \\
$R_{X_{2} X_{1}}$ & 0.741 & & & & & $\operatorname{Cov}\left(X_{1} X_{3}\right)$ & 0.004 \\
$R_{X_{2} X_{3}}$ & -0.17 & & & & & & $\operatorname{Cov}\left(X_{2} X_{3}\right)$ & -0.010 \\
$R_{X_{3} X_{1}}$ & 0.17 & & & & & & \\
\hline
\end{tabular}

An analysis of variance (ANOVA), further shows that F-test $=2018.9$ is higher than criterion $\mathrm{F}(5 \%, 2.9)=$ 4.26, this allowed us to rejet $\mathrm{H}_{0}: \beta_{1}=\beta_{2}=\beta_{3}=0$ and affirm that at least one of the predictors is linearly associated to the response.

for testing the regression coefficients $\beta_{1}, \beta_{2}$ and $\beta_{3}$ and discovering with variable(s) is related to estimate $Y=$ $n_{\mathrm{Ca}}$, we conduct on the one hand individual t-tests on the $\beta$ 's, Hence, for $\beta_{1}, \mathrm{t}=-5.28$, for $\beta_{2}, \mathrm{t}=-28.3$ and for $\beta_{3}, \mathrm{t}=-1.2 \mathrm{t}\left(\beta_{1}\right)$ and $\mathrm{t}\left(\beta_{2}\right)$ are signifiants at $\mathrm{P}>99.9 \%$ level. Thus, the molar $n_{\mathrm{Ca}}$ of Na- $\mathrm{CO}_{3} \mathrm{Aps}$ solid is significantly depends on both a and c contributions of mechanisms I and III. The general formula can be written as follows:

$$
\mathrm{Ca}_{10-(a+c)} \mathrm{Na}_{(c)}\left(\mathrm{PO}_{4}\right)_{6-(a+c)}\left(\mathrm{CO}_{3}\right)_{(a+c)}(\mathrm{OH})_{(2-a)}
$$

Also, structural study for two samples obtained under comparable conditions [28] has been investigated extensively by physicochemical analysis and by Rietveld method refinements. The results of unit cell content calculated from the occupations of the atomic sites and the data of chemical composition $\left(n_{\mathrm{CO}_{3}^{2-}} \cong 3 n_{\mathrm{Na}^{+}}\right)$may be represented by the following ideal substitution scheme and corresponding solid solution :

$$
2 \mathrm{Ca}^{2+}+3 \mathrm{PO}_{4}^{3-} \leftrightarrow \mathrm{V}^{\mathrm{Ca}}+3 \mathrm{CO}_{3}^{2-}+\mathrm{Na}^{+}
$$

(The sum of mechanism II and III)

$$
\mathrm{Ca}_{10-2 / 3 x} \mathrm{Na}_{x / 3} \mathrm{~V}_{x / 3}\left(\mathrm{PO}_{4}\right)_{6-x}\left(\mathrm{CO}_{3}\right)_{x}(\mathrm{OH})_{2} \text {, with } x=1.5(\mathbf{I}) \text { and } 2.4(\mathbf{I I}) \text {. }
$$

These results show that we cannot consider unique and well defined substitution mechanisms resulting in apatites, especially for homogeneous precipitation methods in aqueous solutions, because the lack of control of the reaction parameters as well as incomplete analyses of the solids could result in erroneous interpretations of the substitution mechanism.

On the other hand El Feki et al. [28] confirm that no vacancies of $\mathrm{OH}^{-}$are observed by Rietveld refinements. But, small fraction of vacancies is undetectable by this method and was ignored in the structure refinements.

\section{Conclusion}

The different statistical analyses present in this review mainly focused on original and new approaches of the knowledge of the substitutions mechanisms. However, in biological calcifications, part of lattice ions of Hap are substituted to considerable extent ions. Consequently, these substitutions have an important influence on several processes (the growth, the dissolution, the mineralization and the demineralization processes. In order to derive the fundamental thermodynamic properties of the solid which determine the course of these processes, the stoichiometry of the apatite and especially of the mechanisms by which $\mathrm{CO}_{3}^{2-}$ and $\mathrm{Na}^{+}$are incorporated in the lattice must be known. 


\section{References}

[1] LeGeros, R.Z. (1981) Apatites in Biological Systems. Progress in Crystal Growth and Characterization of Materials, 4, 1-45. http://dx.doi.org/10.1016/0146-3535(81)90046-0

[2] Nagy, G., Lorand, T., Patonai, Z., Montsko, I., Bajnoczky, G., Marcsik, A. and Marka, L. (2008) Analysis of Pathological and Non-Pathological Human Skeletal Remains by FT-IR Spectroscopy. Forensic Science International, 175, 5560. http://dx.doi.org/10.1016/j.forsciint.2007.05.008

[3] Follmi, K.B. (1996) The Phosphorus Cycle, Phosphogenesis and Marine Phosphate-Rich Deposits. Earth-Science Reviews, 40, 55-124. http://dx.doi.org/10.1016/0012-8252(95)00049-6

[4] Frank-Kamenetskaya, O., Kol’tsov, A., Kuz’mina, M., Zorina, M. and Poritskaya, L. (2011) Ion Substitutions and NonStoichiometry of Carbonated Apatite-(CaOH)) Synthesized by Precipitation and Hydrothermal Methods. Journal of Molecular Structure, 992, 9-18. http://dx.doi.org/10.1016/j.molstruc.2011.02.013

[5] Larson, P.R., Madden, A.S. and Tas, A.C. (2013) Non-Stirred Synthesis of Na- and Mg-Doped, Carbonated Apatitic Calcium Phosphate. Ceramics International, 39, 1485-1493. http://dx.doi.org/10.1016/j.ceramint.2012.07.095

[6] Lafon, J.P., Champion, E. and Bernache-Assollant, D. (2008) Processing of AB-Type Carbonated Hydroxyapatite $\mathrm{Ca}_{10-\mathrm{x}}\left(\mathrm{PO}_{4}\right)_{6-\mathrm{x}}\left(\mathrm{CO}_{3}\right)_{\mathrm{x}}(\mathrm{OH})_{2-\mathrm{x}-2 \mathrm{y}}\left(\mathrm{CO}_{3}\right)_{\mathrm{y}}$ Ceramics with Controlled Composition. Journal of the European Ceramic Society, 28, 139-147. http://dx.doi.org/10.1016/j.jeurceramsoc.2007.06.009

[7] Apfelbaum, F., Diab, H., Mayer, I. and Featherstone, J.D.B. (1992) An FTIR Study of Carbonate in Synthetic Apatites. Journal of Inorganic Biochemistry, 45, 4277-4282. http://dx.doi.org/10.1016/0162-0134(92)84016-G

[8] Zendah, H., Khattech, I. and Jemal, M. (2013) Thermochemical and Kinetic Studies of The Acid Attack of "B” Type Carbonate Fluorapatites at Different Temperatures $25^{\circ} \mathrm{C}-55^{\circ} \mathrm{C}$. Thermochimica Acta, 565, 46-51. http://dx.doi.org/10.1016/j.tca.2013.04.033

[9] Yao, F. and LeGeros, R.Z. (2010) Carbonate and Fluoride Incorporation in Synthetic Apatites: Comparative Effect on Physico-Chemical Properties and in Vitro Bioactivity in Fetal Bovine Serum. Materials Science and Engineering C, 30, 3423-3430. http://dx.doi.org/10.1016/j.msec.2009.12.011

[10] Schramm, D.U. and Rossi, A.M (2000) Electron Spin Resonance (ESR) Studies of $\mathrm{CO}_{2}$-Radicals in Irradiated A and B-Type Carbonate-containing Apatites. Applied Radiation and Isotopes, 52, 1085-1091. http://dx.doi.org/10.1016/S0969-8043(00)00046-4

[11] Fleet, M.E. and Liu, X. (2007) Coupled Substitution of Type A and B Carbonate in Sodium-Bearing Apatite. Bi- omaterials, 28, 916-926. http://dx.doi.org/10.1016/j.biomaterials.2006.11.003

[12] Bel Hadj Yahia, F. and Jemal, M. (2010) Structural Analysis and Thermochemistry of B-Type Carbonate Apatites. Thermochimica Acta, 505, 22-32. http://dx.doi.org/10.1016/j.tca.2010.03.017

[13] El Feki, H. (1990) Synthèse et Etude de la Décomposition Thermique d’Hydroxy et de Fluorapatites Carbonatées Phosphocalciques Sodées. Ph.D. Dissertation, Tunis II University, Tunis.

[14] Elliott, J.C. (1994) Structure and Chemistry of the Apatites and Other Calcium Orthophosphates. Elsevier, Amsterdam.

[15] Labarthe, J.C., Bonel, G. and Montel, G. (1973) Sur la Structure et les propriétés des Apatites Carbonatés de type B Phosphocalciques. Annali di Chimica, 8, 289-301.

[16] Vignoles, M., Labarthe, J.C. and Vignoles, C. (1978) Contribution à L'étude Structurale des Apatites Carbonatées de type B. Colloques Internationaux du CNRS, 230, 117-125.

[17] Vignoles, M., Bonel, G., Labarthe, J.C. and Bacquet, G. (1982) Etude Physico Chimique des Apatites Carbonatées Phosphocalciques Semblables à la Francolite. Bull. Minéral., 105, 307-311.

[18] Khattech, I. and Jemal, M. (1985) Etude de la Décomposition Thermique de Fluorapatites Carbonatées. Thermochimica Acta, 95, 119-128. http://dx.doi.org/10.1016/0040-6031(85)80039-3

[19] Khattech, I. and Jemal, M. (1987) Décomposition Thermique de Fluorapatites Carbonatées de Type B “Inverses”. Thermochimica Acta, 118, 267-275. http://dx.doi.org/10.1016/0040-6031(87)80090-4

[20] El Feki, H., Khattech, I., Jemal, M. and Rey, C. (1994) Decomposition thermique d'hydroxyapatites carbonatées sodées Thermal decomposition of carbonated hydroxyapatites containing sodium ions. Thermochimica Acta, 237, 99110. http://dx.doi.org/10.1016/0040-6031(94)85188-3

[21] De Maeyer, E.A.P. and Verbeeck, R.M.H. (1993) Possible Substitution Mechanisms for Sodium and Carbonate in Calciumhydroxyapatite. Bulletin des Sociétés Chimiques Belges, 102, 601-609. http://dx.doi.org/10.1002/bscb.19931020907

[22] Charlot, G. (1966) Les Méthodes de la Chimie Analytique. Masson, Paris.

[23] De Maeyer, E.A.P., Verbeeck, R.M.H. and Nassens, D.E. (1994) Effect of Heating on the Constitution of Na ${ }^{+}-$and $\mathrm{CO}_{3}^{2-}$ Containing Apatites Obtained by Hydrolysis of Monetite. Inorganic Chemistry, 33, 5999-6006. 
$\underline{\text { http://dx.doi.org/10.1021/ic00104a006 }}$

[24] De Maeyer, E.A.P., Verbeeck, R.M.H. and Nassens, D.E. (1994) Optimalization of the Preparation of $\mathrm{Na}^{+}-$and $\mathrm{CO}_{3}^{2-}$ Containing Hydroxyapatites by the Hydrolysis of Monetite. Journal of Crystal Growth, 135, 539-547. http://dx.doi.org/10.1016/0022-0248(94)90145-7

[25] De Maeyer, E.A.P., Verbeeck, R.M.H. and Pieters, I.Y. (1996) Influence of the Solution Composition on the Stoichiometry of $\mathrm{Na}^{+}$- and of $\mathrm{K}^{+}$-Containing Carbonated Apatites Obtained by The Hydrolysis of Monetite. Journal of Crystal Growth, 169, 539-547. http://dx.doi.org/10.1016/S0022-0248(96)00424-1

[26] Snedecor, G.W. and Cochran, W.G. (1980) Statistical Methods. 7th Edition, The Iowa State University Press, Ames.

[27] Borcard, D. (2009) Régression Multiple. Université de Montréal. http://biol09.biol.umontreal.ca/BIO2042/Regr mult.pdf

[28] El Feki, H., Savariault, J.M., Ben Salah, A. and Jemal, M. (2000) Sodium and Carbonate Distribution in Substituted Calcium Hydroxyapatite. Solid State Sciences, 2, 577-586. http://dx.doi.org/10.1016/S1293-2558(00)01059-1 